\title{
HUBUNGAN ANTARA TINGKAT SPIRITUAL DENGAN PERKEMBANGAN DIABETIC FOOT ULCER (DFU) DI KLINIK KITAMURA PONTIANAK
}

\section{(Correlation Between Spiritual Levels with Development of Diabetic Foot Ulcer (DFU) in Kitamura Clinic Pontianak)}

\author{
Meiti Zahara ${ }^{1}$, Sukarni $^{2}$, Usman $^{3}$ \\ ${ }^{1}$ Universitas Tanjungpura / meitizahara@outlook.com \\ ${ }^{2}$ Universitas Tanjungpura / sukarni@ners.untan.ac.id \\ ${ }^{2}$ STIK Muhammadiyah / usmanudan@stikmuhptk.ac.id
}

\begin{abstract}
ABSTRAK
Latar Belakang : Diabetic foot ulcer (DFU) merupakan komplikasi dari diabetes Mellitus yang paling sering terjadi dan semakin meningkat angka kejadiannya. Adanya kekuatan spiritual pada diri pasien dapat menjadi faktor penting dalam menguatkan pasien dalam menghadapi penyakitnya. Spiritualitas sangat berkaitan dengan koping individu, keyakinan dan praktik spiritual sangat membantu pasien dalam melakukan koping terhadap stres dan penyakit. Berdasarkan hal tersebut, peneliti merasa perlu melihat hubungan antara tingkat spiritual dengan perkembangan diabetic foot ulcer (DFU) di Klinik Kitamura Pontianak. Tujuan : Mengetahui hubungan antara tingkat spiritual dan pekembangan diabetic foot ulcer (DFU) di Klinik Kitamura Pontianak. Metode : Penelitian kuantitatif dengan desain analitik korelatif dengan rancangan penelitian kohort prospektif dengan jumlah responden 31 orang. Pengumpulan data dilakukan dengan kuesioner dan pendokumentasian gambar perkembangan luka. Analisis yang digunakan menggunakan uji somers'd. Hasil : nilai $r$ sebesar 0,217 dan nilai tersebut negatif sehingga menunjukkan arah korelasi berlawanan, sedangkan nilai $p$ didapat 0,184 Kesimpulan : Tidak ada hubungan antara tingkat spiritual dan perkembangan DFU.
\end{abstract}

Kata Kunci : diabetes mellitus, perkembangan diabetic foot ulcer, tingkat spiritual

\section{ABSTRACT}

Background : Diabetic Foot Ulcer (DFU) is the most common complication of diabetes mellitus and it's increasing in incidence rates. The existence of spiritual strength in the patient's self can be an important factor in strengthening the patient when facing the illness. Spirituality is closely related to individual coping, spiritual beliefs and practice greatly assist patients in coping with stress and illness. Preliminary study results were obtained in the clinic, some patients showed a good spiritual level, but the DFU did not improve, in contrast there were patients who had lower spiritual levels but faster in healing of DFU. This demonstrates the needs for a study of the relationship of spiritual levels to the development of DFU in order that DFU-related nursing care can be handled holistically. Purpose : To know the correlation between spiritual level and the development of Diabetic Foot Ulcer (DFU) at Kitamura Clinic Pontianak. Method: This research is a quantitative research with correlative analytic design with prospective cohort study design with 31 respondents. The data were collected by questionnaires and documentation of wound developments. The analysis used somers'd test. Results : $r$ value of 0.217 and the value is negative so it shows the direction of the opposite correlation, while the p value is 0.184. Conclusion: There is no relationship between the spiritual level and the development of DFU.

Keywords : diabetes mellitus, development of diabetic foot ulcer, spiritual level 


\section{PENDAHULUAN}

Diabetes

Mellitus

(DM)

merupakan penyakit kronis yang banyak diderita oleh penduduk dunia. Menurut International Diabetes Federation (IDF), tahun 2013 terdapat 382 juta orang mengidap penyakit diabetes di dunia. Indonesia menjadi negara dengan urutan ke-4 dengan jumlah kematian yang disebabkan oleh $\mathrm{DM}^{1}$ dan menurut Riskesdas tahun 2013, jumlah penderita DM sebesar 2 juta orang ${ }^{2}$. Kejadian diabetes di Kalimantan Barat mengalami peningkatan dari jumlah penderita diabetes yang dilaporkan oleh Dinas Kesehatan Kota Pontianak ${ }^{2,3}$ sejumlah 872 kasus, sedangkan tahun 2016 sejumlah 999 kasus dan mengalami peningkatan sebesar $300 \%$ atau 3024 kasus pada tahun $2017^{2,3}$.

Penelitian yang dilakukan oleh Park (2017) membuktikan tingginya angka kejadian DM menyebabkan terjadinya peningkatan pada komplikasi seperti retinopati diabetik, nefropati diabetik, stroke, penyakit arteri koroner, Diabetic Foot Ulcer (DFU) dan beberapa penyakit lain. Komplikasi yang sering terjadi pada penderita DM ialah DFU. Penelitian menunjukkan bahwa sebanyak 15-25\% pasien DM terkena DFU selama hidupnya dan 59\% pasien dengan DFU harus diamputasi karena infeksi yang terjadi akibat luka tersebut ${ }^{5,6,7}$.

Diabetic Foot Ulcer (DFU) menyebabkan rasa nyeri, menghambat mobilitas pasien, timbulnya bau busuk dan luka yang basah, sehingga menyebabkan meningkatkan frekuensi penggantian dressing. Hal ini berdampak pada perubahan fisik, emosi, dan psikologi pasien dan menyebabkan gangguan tidur, depresi, kecemasan, dan kurangnya perawatan diri. Hal ini menyebabkan pasien mengalami fase stres dalam menghadapi penyakitnya ${ }^{8,9}$.

Diabetic Foot Ulcer (DFU) juga memberi dampak negatif pada konsep diri pasien, penghargaan diri sendiri, kualitas hidup, kesehatan fisik dan emosi, harapan pasien untuk sembuh, dan tingkat spiritual pada pasien. Hal ini menunjukkan bahwa penanganan pada DFU tidak cukup hanya dengan merawat fisiknya saja, namun juga perlu adanya perhatian dalam penanganan sisi psikis, spiritual, dan harapan pasien ${ }^{7,10,11}$.

Spiritual merupakan pencarian seseorang mengenai makna hidup yang mendalam mengenai hubungan sesuatu dengan kesucian dan dapat berhubungan terhadap suatu agama maupun tidak. Adanya kekuatan spiritual pada diri pasien dapat menjadi faktor penting dalam menguatkan pasien dalam menghadapi penyakitnya. Keberhasilan pasien dalam menghadapi penyakit yang dideritanya akan membentuk kembali identitas diri dan hidup pasien menjadi lebih baik ${ }^{12,13,14}$.

Penelitian yang telah dilakukan oleh Koenig, didapatkan bahwa seseorang dengan spiritualitas yang baik, akan memperbaiki fungsi sistem imunitas tubuh, menurunkan angka kematian akibat kanker, dan mengurangi kejadian penyakit jantung. Hal ini menunjukkan perlunya dilakukan sebuah penelitian terkait hubungan tingkat spiritual terhadap perkembangan DFU agar penanganan keperawatan terkait DFU dapat ditangani secara holistik ${ }^{15}$.

\section{METODE PENELITIAN}

Penelitian ini merupakan penelitian kuantitatif dengan desain analitik korelatif dengan rancangan penelitian kohort prospektif. Populasi dalam penelitian ini adalah 81 pasien luka kaki diabetes yang dirawat di klinik Kitamura mulai dari Februari 2018. Penelitian dimulai Mei 2018 hingga Juli 2018, yang dimulai dari kegiatan pengumpulan data, dilanjutkan dengan pengolahan hasil serta penulisan laporan penelitian.

\section{HASIL PENELITIAN}

Hasil penelitian mengenai hubungan antara tingkat spiritual dan 
perkembangan Diabetic Foot Ulcer (DFU) akan dijelaskan pada bab ini. Penelitian ini dilakukan di Klinik Kitamura Pontianak yang dilakukan pada tanggal 18 Mei hingga 10 Juli 2018 dengan jumlah responden sebanyak 31 orang. Pengambilan data pada penelitian ini dilakukan dengan cara pengisian kuesioner oleh pasien DFU dan juga pengukuran skor luka Bates Jensen Assessment Tool (BJWAT). Responden akan diukur tingkat spiritualnya

Tabel 1.1

Distribusi responden berdasarkan Umur, Jenis Kelamin, Pekerjaan, Suku, Agama, Tingkat Spiritual Dan Perkembangan DFU.

\begin{tabular}{lcc}
\hline Variabel & F & \% \\
\hline Usia & & \\
$45-55$ & 10 & 32,3 \\
$55-65$ & 11 & 35,5 \\
$>65$ & 10 & 32,3 \\
\hline Jenis Kelamin & & \\
Laki laki & 14 & 45,2 \\
Perempuan & 17 & 54,8 \\
Pekerjaan & & \\
PNS & 3 & 9,7 \\
Swasta & 4 & 12,9 \\
Petani & 1 & 3,2 \\
IRT & 14 & 45,2 \\
Buruh & 2 & 6,5 \\
Pensiun & 7 & 22,6 \\
\hline
\end{tabular}

Tabel 4.2

Hubungan tingkat spiritualitas dan perkembangan DFU di Klinik Kitamura Pontianak

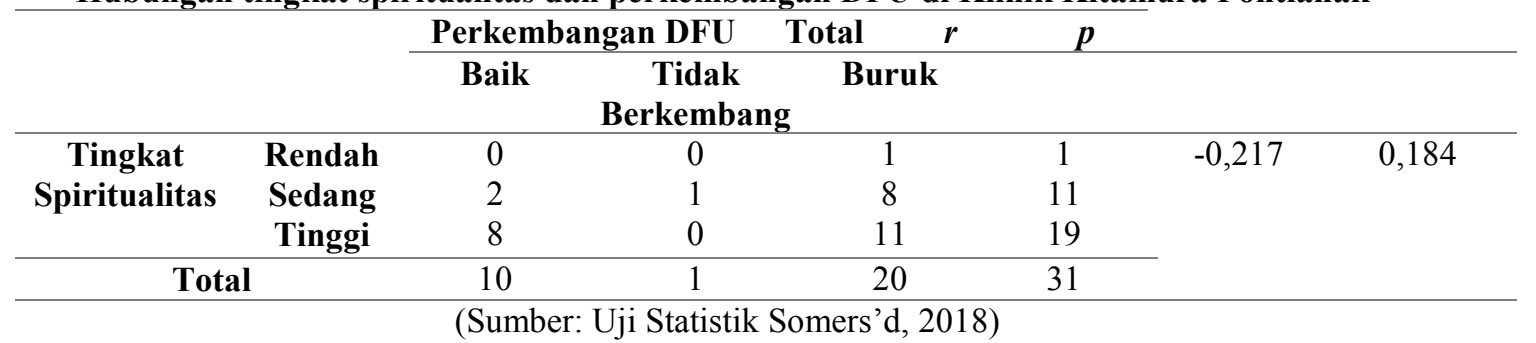

Usia terbanyak dalam penelitian ini ialah lansia menengah yaitu sebesar $35,5 \%$ dan pada lanjut usia awal dan akhir didapat jumlah yang sama yaitu $32,3 \%$. Jenis kelamin yang dominan terkena DFU ialah wanita yaitu sebanyak $54,8 \%$. Pekerjaan terbanyak ialah Ibu Rumah Tangga (IRT) sebanyak 45,2\% dan yang

sebanyak satu kali dan diukur perkembangan lukanya selama 2 kali pada minggu pertama dan ketiga. Analisa data statistik hasil penelitian univariat dan bivariat.

\section{Hasil Analisa Univariat}

Karakteristik responden meliputi usia, jenis kelamin, pekerjaan, suku, agama, tingkat spiritual dan perkembangan DFU.

\begin{tabular}{lcc}
\hline Tingkat Spiritual & & \\
Tinggi & 19 & 61,3 \\
Sedang & 11 & 35,5 \\
Rendah & 1 & 3,2 \\
\hline Perkembangan DFU & & \\
Baik & 10 & 32,3 \\
Buruk & 20 & 64,5 \\
Tidak Berkembang & 1 & 3,2 \\
\hline Ankle Branchial & & \\
Index (ABI) & 18 & 58,1 \\
Normal & 8 & 25,8 \\
Tinggi & 5 & 16,1 \\
Rendah & & \\
\hline & & \\
Variabel & $\mathrm{f}$ & $\%$ \\
GDS & & \\
$<150$ & 1 & 3,2 \\
151-200 & 2 & 6,5 \\
$>200$ & 25 & 80,6 \\
\hline Sumber: (Uji Statistik, 2018) &
\end{tabular}


dan paling sedikit tidak mengalami perkembangan sebanyak 3,2\%. Ankle Brachial Index (ABI) yang paling banyak berada dalam rentang normal yaitu $58,1 \%$ dan sebanyak $16,1 \%$ memiliki ABI rendah. Gula Darah Sewaktu (GDS) yang paling banyak berada di angka lebih dari $200 \mathrm{mg} / \mathrm{dl}$ sebanyak $80,6 \%$ dan GDS yang berada dalam rentang kurang dari 150 hanya sebesar 3,2\%.

\section{Hasil Analisa Bivariat}

Analisa bivariat dilakukan untuk mengetahui hubungan tingkat spiritualitas dan perkembangan DFU di Klinik Kitamura Pontianak. Berdasarkan tabel 4.2 dapat diketahui bahwa jumlah responden terbanyak yaitu tingkat spiritual tinggi memiliki perkembangaan DFU yang buruk sebanyak 11 orang, sedangkan responden yang memiliki tingkat spiritual sedang terdapat 2 orang yang mengalami perkembangan luka baik, 1 orang lukanya tidak berkembang, dan 11 orang mengalami perkembangan luka yang buruk. Selanjutnya tidak terdapat responden dengan tingkat spiritualitas rendah yang memiliki perkembangan DFU yang baik. Analisis lebih lanjut diperoleh nilai $r$ sebesar 0,217 dan nilai tersebut negatif sehingga menunjukkan arah korelasi berlawanan, sedangkan nilai $p$ didapat 0,184

\section{PEMBAHASAN}

\section{Karakteristik Responden} Usia

Hasil penelitian menunjukkan jumlah responden responden terbanyak ada pada rentang usia 55-65 tahun. Penelitian yang dilakukan di Universiti Sains Malaysia Hospital menunjukkan sebesar $80,6 \%$ pasien berusia lebih dari 50 tahun. Penelitian di Srilangka juga menunjukkan bahwa sebesar $68,3 \%$ pasien berusia lebih dari 50 tahun. Usia lebih dari 45 tahun akan berisiko mengalami diabetes melitus tipe 2 karena terjadi penurunan aktivitas, perubahan metabolisme karbohidrat, penurunan sekresi insulin dan resistensi insulin $^{17,18}$. Adanya hasil penelitian yang telah banyak dilakukan menunjukkan bahwa meningkatnya usia dapat menjadi predikor terjadinya Diabetic Foot Ulcer (DFU). Usia tua berisiko mengalami diabetes karena terjadi penurunan fungsi pangkreas sehingga reaksinya terhadap insulin menurun ${ }^{19}$.

Proses penuaan banyak mempengaruhi kondisi kulit dan jaringan seseorang sehingga mudah mengalami cedera dan kemampuan untuk pulih semakin berkurang. Perubahan yang paling signifikan ialah pada berkurangnya respon inflamasi, berkurangnya produksi sitokin, berkurangnya reseptor sitokin, dan meningkatnya jumlah sel-sel senescent (sel yang tidak mampu berespon terhadap sitokin) ${ }^{17,18}$. Menurut peneliti, hal ini terjadi karena pada usia ini tubuh pasien semakin mengalami penurunan kinerja sistem tubuh terutama pada sistem integumen dimana pasien semakin rentan mengalami perlukaan dan juga tubuh semakin lambat dalam proses penyembuhan.

\section{Jenis Kelamin}

Hasil penelitian yang telah dilakukan menunjukkan bahwa responden terbanyak adalah berjenis kelamin perempuan dengan jumlah 17 orang $(54,8 \%)$ dan jumlah laki laki sebesar 14 orang $(45,2 \%)$. Hal ini dikarenakan populasi responden perempuan lebih tinggi. Penelitian ini sejalan dengan yang dilakukan oleh Dewi (2007) dimana 21 responden perempuan berjumlah 15 orang $(71,4 \%)$ dan dan responden laki-laki sebanyak 6 orang $(38,6 \%)$.

Bertolak belakang dengan penelitian Shakil dan Khan yang dilakukan di India mengenai infeksi DFU menunjukkan jumlah penderita yang lebih besar adalah laki laki sebesar $83,65 \%{ }^{20}$. Penelitian yang dilakukan 
oleh Sriyani, Wasalanthanth, Hettiarachchi, dan Prathapan menyatakan jenis kelamin pria menjadi bagian dari faktor risiko karena lebih tinggi berisiko mengalami kecelakaan kerja $^{21}$. Asumsi peneliti, perempuan dalam penelitian ini lebih dominan dapat disebabkan oleh tingkat stres yang lebih tinggi dikarenakan faktor usia yang semuanya memasuki masa monopause sehingga koping dalam menerima keadaan dirinya buruk dan menyebabkan kadar gula darah juga semakin tinggi sehingga mudah mengalami perlukaan dan penyembuhan luka menjadi terhambat.

\section{Pekerjaan}

Hasil penelitian menunjukkan pekerjaan terbanyak dari responden penelitian ialah Ibu Rumah Tangga (IRT) yaitu sebanyak 14 orang $(45,2 \%)$. Hal ini sejalan dengan penelitian yang dilakukan oleh Junaidi di Klinik Kitamura Pontianak didapatkan bahwa responden terbanyak ialah IRT sebanyak 24 orang $(38,1 \%)^{16}$. Tingginya IRT yang terkena DFU diduga karena pola aktivitas di dalam rumah tangga yang terkadang dapat membuat responden kurang memperhatikan gula darahnya sehingga tidak terkontrol dan menimbulkan luka secara tiba-tiba. Selain itu, IRT juga menghabiskan sebagian besar waktunya di dalam rumah sehingga kurang mendapatkan pengetahuan terkait diabetes dan luka diabetes sehingga pola hidupnya kurang terkontrol dan memicu terjadinya DFU.

\section{Tingkat Spiritual}

Penelitian ini menunjukkan responden terbanyak memiliki tingkat spiritual tinggi yaitu sebanyak 19 orang $(61,3 \%)$. Hal ini bertolak belakang dengan penelitian Junaidi (2017) yang mendapatkan hasil responden terbanyak memiliki tingkat spiritual yang rendah yaitu sebanyak 35 orang $(55,6)$. Hal ini dapat terjadi karena perbedaan jumlah sampel yang digunakan oleh peneliti. Jumlah sampel yng digunakan Junaidi lebih besar yaitu 63 responden daripada yang digunakan dalam penelitian ini sebanyak 31 responden. Menurut peneliti, sebagian besar pasien memiliki tingkat spiritual tinggi karena mereka merasa luka yang mereka alami sudah sangat parah sehingga tidak ada yang dapat menyembuhkan kecuali hanya Tuhan dan membuat mereka semakin ingin mendekatkan diri kepada Tuhan karena sakit yang mereka alami.

\section{Perkembangan DFU}

Hasil penelitian menunjukkan tingkat perkembangan DFU buruk menempati jumlah terbanyak dengan 20 responden atau sebesar $48,4 \%$. Hal ini terjadi karena beberapa dari responden ada yang mengalami luka iskemik sehingga terjadi kerusakan perfusi sehingga menghambat kesembuhan luka. Selain itu perkembangan DFU juga dipengaruhi oleh tekanan pada kaki atau alas kaki yang digunakan ${ }^{17,21}$. Hal ini didukung dengan hasil wawancara pada responden karena sering menggunakan kaki yang luka untuk berjalan terlalu sering sehingga terkadang seringkali menjadikan kaki tersebut sebagai tumpuan dan menyebabkan peningkatan tekanan pada kaki sehingga kesembuhan luka menjadi terhambat. Selain itu, perkembangan DFU yang buruk juga dapat disebabkan oleh kadar gula darah yang tidak terkontrol sehingga luka kurang mendapat asupan nutrisi dan kesembuhannya menjadi lambat.

\section{Ankle Branchial Index (ABI)}

ABI digunakan untuk mengukur tekanan darah pada area tungkai, kemudian nilai ini dibagi dengan nilai tekanan darah brankial pada bagian tubuh yang sama (kanan-kanan atau kirikiri). Berdasarkan hasil penelitian, sebesar $58,1 \%$ responden memiliki nilai abi normal yaitu berkisar antara $(0,8-$ 1,1). Jumlah responden terbanyak selanjutnya memiliki nilai $\mathrm{ABI}$ yang tinggi $(>1,1)$ sebanyak $25,8 \%$, hal ini mengindikasikan terdapat penyakit arteri 
perifer pada responden tersebut ${ }^{22}$. Berdasarkan hasil wawancara dengan responden, mereka sering mengalami pembengkakan pada kaki apabila berjalan terlalu sering. Hal ini semakin menguatkan adanya gangguan arteri perifer pada responden yang diperiksa.

\section{Gula Darah Sewaktu (GDS)}

Hasil penelitian menunjukkan jumlah terbanyak responden memiliki GDS yang tinggi, yaitu sebanyak $80,6 \%$ responden memiliki nilai GDS lebih dari $200 \mathrm{mg} / \mathrm{dl}$. Kadar gula darah yang tinggi dapat menghambat perfusi pada jaringan sehingga penderitanya berisiko tinggi mengalami penyakit mikrovaskular. Hal ini menyebabkan hantaran mikronutrien pada pembuluh kapiler menjadi terhambat dan membuat peningkatan permeabilitas vaskular menjadi meningkat. Akhirnya hal ini membawa dampak peningkatan infeksi dan memperlambat kesembuhan luka. Selanjutnya, hiperglikemi membuat tubuh mem produksi AGEs, dimana ia akan menyebabkan peningkatan stres oksidatif dan lebih lanjut akan terjadi hipoksia pada sel-sel tubuh ${ }^{4,11}$. Hal ini juga memperkuat bukti bahwa responden terbanyak mengalami perkembangan luka yang buruk, yaitu sebesar 48,4\%.

\section{Analisis Bivariat}

\section{Hubungan antara tingkat spiritualitas} terhadap perkembangan DFU

Dari hasil penelitian ini didapakan bahwa tidak terdapat hubungan antara tingkat spiritual dan perkembangan DFU. Hal ini ditunjukkan dengan nilai $p$ sebesar 0,184 $(p>0,05)$, maka dapat diambil kesimpulan bahwa tidak terdapat hubungan antara tingkat spiritualitas dan perkembangan DFU di Klinik Kitamura Pontianak. Spiritualitas dikaitkan dengan pola koping individu dan perilaku perawatan diri pasien dengan $\mathrm{DM}^{23}$. Studi cross-sectional yang dilakukan terhadap muslim di Iran menunjukkan $64 \%$ responden dengan DM mengalami depresi terkait kondisi kesehatannya ${ }^{13}$. Kaitannya dengan depresi pula dapat dihubungkan dengan pilihan terapi dan kepatuhan pasien DM dalam menjalankan terapi. Hal ini juga didukung sebuah review artikel oleh Koenig yang menunjukkan terdapat banyak hasil penelitian yang menunjukkan besarnya implikasi aspek spiriual terhadap kesehatan mental maupun fisik individu ${ }^{15}$.

Namun, terlepas dari tidak adanya hubungan antara tingkat spiritual dan perkembangan DFU, sumber-sumber spiritual dapat membantu penderita DM dalam mengelola penyakit DM secara lebih baik sehingga dapat meningkatkan kualitas hidup dan memperbaiki hidup mereka $^{24}$. Penderita DM yang memiliki tingkat spiritual tinggi dapat menggunakan kepercayaan dalam berkoping terhadap penyakit, nyeri dan tekanan hidup. Agama dan spiritualitas membentuk dasar makna dan tujuan bagi banyak orang. Spiritualitas memberikan bekal bagi penderita DM untuk memaknai penyakit yang mereka alami sebagai suatu peristiwa hidup yang positif. Asuhan keperawatan yang ditujukan untuk mempertahankan kualitas hidup penderita DM sekaligus meningkatkan kepatuhan terhadap manajemen terapi ${ }^{25}$.

Tingkat spiritual yang baik dapat mengurangi dampak negatif yang disebabkan oleh luka kronik. Spiritualitas dapat meningkatkan rasa penerimaan pada pasien, menjaga ketahanan pasien terhadap penyakitnya, memberikan ketenangan, meningkatkan kepercayaan dirinya, dan menjadikan gambaran diri menjadi positif. Spiritualitas juga berkaitan dengan penurunan tingkat depresi, peningkatan harapan dan perbaikan diri, dan memiliki korelasi yang positif terhadap kualitas hidup secara umum ${ }^{6}$.

Adanya aspek spiritualitas yang baik pada penderita DFU akan berpengaruh pada tingkat stres yang dialaminya. Hal ini juga berperan dalam 
perbaikan luka yang dialami pasien. Mekanisme terjadinya perbaikan luka ialah dimulai dengan adanya tingkat spiritual yang baik dapat membuat perasaan seseorang menjadi rileks dan tentram. Di dalam sistem saraf manusia terdapat saraf otonom dan sistem saraf pusat. Fungsi saraf pusat adalah mengendalikan gerakan-gerakan yang dikehendaki, misalnya gerakan tangan, kaki, leher, dan jari-jari. Sedangkan sistem saraf otonom berfungi mengendalikan gerakan-gerakan yang otomatis, misalnya fungsi digestif, proses kardivaskuler, dan gairah seksual sehingga saat tubuh merasakan rileks, maka kinerja saraf parasimpatis dirangsang sehingga menekan dari fungsi saraf simpatis sehingga peredaran darah dapat mengalir lancar dan mencegah terjadinya mekanisme perlambatan penyembuhan DFU seperti yang dijelaskan sebelumnya. Hal ini menyebabkan perbaikan DFU dapat berkembang secara fisik dan juga psikis dengan adanya spiritual yang baik pada pasien $^{13,23}$.

Perawatan spiritual adalah hal yang essensial untuk penyembuhan selama proses perawatan fisik dan psikologis dalam asuhan keperawatan. Aspek spiritualitas sangat relevan diterapkan pada penderita diabetes karena kompleksitas perawatan diabetes, kebutuhan untuk perawatan diri seumur hidup dan sifat tak terduga pada kondisi kronis diabetes. Hasil penelitian telah menunjukkan ada hubungan antara spiritualitas dan menerima kenyataan hidup dengan penyakit kronis ${ }^{12}$.

\section{Keterbatasan Penelitian}

Pasien memiliki latar belakang dan karakteristik berbeda terutama pada pasien rawat jalan dan pasien home care. Pasien rawat jalan lebih sering datang ke klinik sendirian dan pasien home care lebih banyak didampingi oleh keluarga atau orang terdekat sehingga hal ini mempengaruhi psikologi pasien dan spiritual pasien. Pasien yang didampingi oleh keluarga cenderung memiliki tingkat spiritual yang lebih baik daripada pasien yang hanya menjalani perawatan sendirian. Adanya perbedaan ini menjadi penyebab adanya faktor lain yang mempengaruhi tingkat spiritual pasien dan juga perkembangan DFU.

Pasien tidak bisa mengisi kuesioner sendiri sehingga peneliti yng membantu mengisi kuesioner dan hal ini dikhawatirkan menjadi bias dalam penelitian dan hasil yang didapat kurang akurat.

Pelaksanaan penelitian dilakukan bertepatan pada bulan puasa dan lebaran sehingga pasien sering lupa menjaga makanan tinggi gula dan menyebabkan kadar gula darah meningkat dan luka sulit sembuh.

\section{PENUTUP}

\section{Kesimpulan}

Berdasarkan karakteristik responden di Klinik Kitamura Pontianak, sebagian besar responden berusia 55-65 tahun, berjenis kelamin wanita, bekerja sebagai Ibu Rumah Tangga, memiliki tingkat spiritual tinggi, perkembangan luka buruk, memiliki ABI normal, dan GDS > 200 . Penelitian ini menunjukkan tidak ada hubungan antara tingkat spiritual dan perkembangan DFU.

\section{Saran}

Bagi pelayanan keperawatan, Tenaga keperawatan diharapkan dapat mendorong pasien DM untuk mengontrol GDS secara berkala. Tenaga keperawatan diharapkan lebih memperhatikan aspek spiritual dalam keperawatan pasien DM.

Bagi institusi pendidikan, hasil penelitian diharapkan dapat menjadi dasar penerapan keperawatan dalam aspek spiritual. Bagi penelitian lebih lanjut. Bagi Penelitian lebih lanjut, dapat ditambahkan variabel lain, seperti dukungan keluarga dan dengan masalah 
yang sama dalam sampel yang lebih besar.

\section{DAFTAR PUSTAKA}

1. Yuanita, A. (2013). Pengaruh Diabetes Self Management Education (DSME) Terhadap Risiko Terjadinya Ulkus Diabetik pada Pasien Rawat Jalan dengan Diabetees Mellitus (DM) Tipe 2 di RSD dr. Soebandi Jember. Skripsi tidak dipublikasikan

2. Infodatin Pusat Data Dan Informasi Kementerian Kesehatan RI. (2013, November 14). Situasi dan Analisis Diabetes

3. Astrada, A. (2014). FaktorFaktor yang Mempengaruhi Terjadinya Luka Kaki Diabetik pada Pasien Diabetes Mellitus Tipe 2 di Balai Pengobatan dan Spesialis Perawatan Luka, Stoma, dan Inkontinensia "Kitamura" Pontianak pada Tahun 2014

4. Park, J. H., Suh, D. H., Kim, H. J., Lee, Y. I., Kwak, I. H., \& Choi, G. W. (2017). Role of Procalsitonin in Infected Diabetic Foot Ulcer.

ELSEVIER. Doi: 10.1016/j.diabres.2017.04.008

5. Salome, G. M., Almeida, S. A., Mendes, B., Calvalho, M. R., Bueno, J. C., Massahud, M. R., \& Ferreira, L. M. (2017). Association of Sociodemographic Factors with Spirituality and Hope in Patients with Diabetic Foot Ulcers. ADVANCE IN SKIN \& WOUND CARE. Doi: 10.1097/01.ASW.0000508446. 58173.29
6. Salome, G., Alves, S., Costa, V. F., Perelra, V., \& Ferreira, L. M. (2013). Feeling of powelessness and hope for cure in patients with chronic lower-limb ulcers. Journal of wound care.

7. Salome, G., Pereira, V., \& Ferreira, L. (2015). Spirituality and Subjective Wellbeing in Patients with Lower-Limb Ulceration. Journal of Wound Care. Doi: 10.12968/jowc.2013.22.5.230

8. Lefrancois, T., Mehta, K., Sullivan, V., Lin, S., \& Glazebrook, M. (2016).

Evidence Based Review of Literature on Detriments to Healing of Diabetic Foot Ulcer. Doi: 10.1016/j.fas.2016.04.002

9. Kamolz, L.-P., \& Wild, T. (2013). Wound Bed Preparation : The Impact of Debridement and Wound Cleansing. ELSEVIER, 44-50. Doi: 10.1016/j.wndm.2013.03.006

10. Astuti. (2014). Hubungan Tingkat Stres dengan Penyembuhan Luka Diabetes Mellitus. Universitas Sumatera Utara. Skripsi tidak dipublikasikan

11. Bryant, R. A. (2007). Acute \& Chronic Wounds: Current Management Concept. United States of America: ELSEVIER

12. Dunning, T. (2013). Spirituality: An Essential Aspect of Holistic, Individualised Diabetes Education. Australian Diabetes Educator

13. Husna, C., \& Linda, C. N. (2014). Hubungan Spiritualitas 
dengan Harga Diri Pasien Ulkus Diabetik di Poliklinik Endokrin Rumah Sakit Umum Daerah dr. Zainoel Abidin Banda Aceh Tahun 2014. Idea Nursing Journal.

14. Mayrani, E. D., \& Hartati, E. (2013). Intervensi Terapi Audio Murottal Surah Ar-rahman pada Penderita Ulkus Diabetik.

15. Koenig, H. G. (2004). Religion, Spirituality, and Medicine: Research Findings and Implication for Clinical Practice. Shouthern Medical Association.

16. Junaidi. (2017). Hubungan Karakteristik Spiritual dengan Kepatuhan Perawatan Diabetic Foot Ulcer di Klinik Spesialis Perawatan Luka Kitamura Pontianak. Skripsi tidak dipublikasikan

17. Chadwick. (2013). Best Practice Guidelines: Wound Management in Diabetic Foot Ulcer. Wound International.

18. Sinclair, A. (2009). Diabetes in Old Age. Chichester: John Wiley \& Sons Ltd.

19. DeFronzo, R. A., Ferranini, E., Groop, L., Henry, R. R., Herman, W. H., Holst, J. J., . . . Weiss, R. (2015). Type 2 Diabetes Mellitus. NATURE REVIEWS.

Doi:

10.1038/nrdp.2015.19
20. Khan, S. S. (2010). Infected Foot Ulcer in Male and Female Diabetic Patient: A ClinicoBioinformative Study. Annals of Clinical Microbiology and Antimicrobials, 1-10.

21. Sriyani, K. A., Wasalathanth, S., Hettiarachchi, P., \& Prathapan, S. (2013). Predictors of Diabetic Foot and Leg Ulcers in Developing Country with A Rapid Increase in the Prevalence of Diabetes Mellitus . PloSONE, 1-6.

22. Wu, S., Driver, V., \& Wrobel, J. (2007). Foot Ulcers in The Diabetic Patient, Prevention and Treatment. Vasc Health Risk Manag, 65-76.

23. S., H. (2013). Gambaran Kualitas Hidup dan Tingkat Stres Penderita Ulkus Diabetik. Universitas Hasanudin.

24. Setyoningrum, I. A., Armiyati, Y., \& Astuti, R. (2013). Tingkat Depresi Berdasarkan Derajat Ulkus Diabetik pada Pasien Ulkus Diabetes Mellitus yang Berobat di Rsud Kota Semarang.

25. Sara, S., \& Mohammad, H. (2013). Effect of Quran and Music on Anxiety in Patients during Endoscopy. Knowledge and Health. 